\title{
Collaborate and Innovate: The Impact of Academic Librarians on the Commercialization of University Technology
}

\begin{abstract}
The University of Arizona Library, in collaboration with the campus commercialization unit, created a partnership that contributes to the early development of inventions in the commercialization pipeline. The library-commercialization business-intelligence workgroup was incorporated into the overall campus commercialization business-development workflow in 2014 and is comprised of librarians and commercialization professionals working together to provide insight and decision support for development of commercialization strategies for inventions emerging from university research that aligns with market drivers. These efforts are recognized by university leadership as critical to the strategic plan of the university. This article discusses the impact of the workgroup and how the group of librarians contributed to the development of new companies, new licenses, and financial impact of economic development at a large land-grant university and larger community.
\end{abstract}

\section{Keywords:}

campus partnerships, technology transfer, academic libraries, business librarianship, commercialization, collaboration, librarians, economic development, technology assessment, market research, business intelligence, innovation

CORRESPONDING AUTHOR: ELLIOTT, CYNTHIA, M.A., RESEARCH AND LEARNING DEPARTMENT, UNIVERSITY OF ARIZONA LIBRARIES, TUCSON, ARIZONA, UNITED STATES, CELLIOTT@EMAIL.ARIZONA.EDU

\author{
DEWLAND, JASON, M.A., M.B.A RESEARCH AND LEARNING DEPARTMENT, \\ UNIVERSITY OF ARIZONA LIBRARIES, TUCSON, ARIZONA, UNITED STATES, \\ JASONDEWLAND@EMAIL.ARIZONA.EDU
}


MARTIN, JENNIFER R., M.A., RESEARCH AND LEARNING DEPARTMENT, UNIVERSITY OF ARIZONA HEALTH SCIENCES LIBRARY, UNIVERSITY OF ARIZONA LIBRARIES, TUCSON, ARIZONA, UNITED STATES, JSWIFT@EMAIL.ARIZONA.EDU

KRAMER, SANDRA, M.A., M.S., RESEARCH AND LEARNING DEPARTMENT, UNIVERSITY OF ARIZONA HEALTH SCIENCES LIBRARY, UNIVERSITY OF ARIZONA LIBRARIES, TUCSON, ARIZONA, UNITED STATES, SKRAMER@EMAIL.ARIZONA.EDU

JACKSON, JOHN, M.B.A, ARIZONA CENTER FOR ACCELERATED BIOMEDICAL INNOVATION, UNIVERSITY OF ARIZONA, TUCSON, ARIZONA, UNITED STATES, JOHNJACKSON@SHC.ARIZONA.EDU

RECEIVED: APRIL 27, 2016

ACCEPTED: JUNE 20, 2016 


\section{Collaborate and Innovate: The Impact of Academic Librarians on the Commercialization of University Technology}

In 2013, an informal partnership formed between the University of Arizona Library (UAL) and its technology commercialization unit. At that time the technology transfer unit, called Tech Launch Arizona (TLA), was realigning to better meet the needs of university inventors and become more competitive in the marketplace. Two librarians, Jason Dewland and Cynthia Elliott, met with the head of this group and gained insight on what TLA was hoping to accomplish. The librarians saw this reorganization as an opportunity to be entrepreneurial, establish connections, and collaborations. The librarians, who came from the corporate environment, were familiar with this work, in which this type of research and decision support is embedded deeply into the culture and work of librarians working in industry. The librarians saw an opportunity to leverage their skillset within the university setting, specifically in this context. A meeting was set up with other executives within the technology transfer unit to share ideas and pitch services that would align closely with their vision. During this phase, the librarians wrote a book chapter outlining the skills and abilities needed to support a campus commercialization unit (Dewland \& Elliott, 2015).

\section{Literature review}

The results of commercialization on campus are expressed in academic works, but the library's role as a campus partner is not adequately addressed in the literature. The Association of University Technology Managers (AUTM)'s 2014 report states that over $\$ 518$ billion has been generated by university technology transfer units from 1996 to 2013 (AUTM, 2014). The Bayh-Dole Act of 1980 was a major turning point in higher education's ability to profit from its intellectual property (IP) (AUTM, 2010). The Bayh-Dole Act states that institutions of higher education own their IP and encourages them to profit from their creations by forming institutionally supported start-ups or collaboration with existing companies in the form of licensing agreements (AUTM, 2010; Lolse \& Stevens, 2010; Mowery, Nelson, Sampat, \& Ziedonis, 2001).

The impact of the Bayh-Dole Act can't be overstated (Aldridge \& Audretsch, 2011; Fairburn \& Hallman, 2013; Grimaldi, Kenney, Siegel, \& Wright, 2011) since its implementation, universities have created over 6,100 new companies, signed an estimated 5,435 licensing agreements executed in 2013 alone (AUTM, 2014), and have been granted over 5,145 patents in 2012 compared to only 300 in 1980 
(AUTM, 2013). Prior to induction of the Act in 1979, there were a total of 24 research parks associated with universities; and after the act passed in the 1980s, over 100 were created (Geiger \& Sa, 2008). In their comprehensive work, Tapping the Riches of Science (2008), Geiger and Sa trace the history of university innovations coming to market, back to Benjamin Silliman of Yale as a pioneer in academic and commercial cooperation beginning in 1840 (p.8) and point out significant acts of Congress, including the 1862 Morrill Land-Grant Act (p.8), the Hatch Act of 1887 (p.8), and the Defense Department's and the NIH's roles in funding research after WWII.

There is significant analysis of the tech transfer process in higher education and research periodicals like The Journal of Technology Transfer and the International Journal of Technology Transfer and Commercialisation. Geiger's solo work, Knowledge and Money:research universities and the paradox of the marketplace (2004), provides an in-depth analysis of how academic research reaches industrial production in the modern university. His research also discusses the inherent tension between academic integrity and the need to monetize research. Geiger and Sa (2008) examine technology transfer and the university in their book, Tapping the Riches of Science: Universities and the Promise of Economic Growth, and find that for some universities, there are riches to be had in the tech-transfer process, but overall the fees gained from licensing and startups is relatively small compared to the institution's overall budget. Sa leads the Centre for the Study of Canadian and International Higher Education at Ontario Institute for Studies in Education (OISE) at the University of Toronto, where there is significant focus on technology transfer, innovation, and entrepreneurship in Canadian universities.

For briefer treatments of the technology transfer and the university, The Chicago Handbook of University Technology Transfer and Academic Entrepreneurship (Siegel \& Wright, 2015) is an attempt to provide a comprehensive analysis of scholarly research on tech transfer and entrepreneurship at academic institutions. In 2015, Siegel and Wright provide a comprehensive review of literature in their chapter, "University Technology Transfer Offices, Licensing, and Start-Ups." They review the theoretical role of technology transfer, effectiveness of the offices, and an overview of the research about university startups after they are launched. They also examine how entrepreneurial education can support or enhance the university's efforts to assist the technology transfer process (Siegel \& Wright, 2015). Nelson and Byers (2015), while stressing the benefits of engaging entrepreneurial education in the technology-transfer process warn that, "The siren song of start-ups, management titles, prize money, and investors can be alluring to students, faculty, and administrators alike. Focusing entrepreneurship education efforts primarily upon technology transfer efforts, however, sacrifices the incredible breadth of the field for a very high-risk low-probability outcome with a limited educational impact” (p.157). 
Other research has examined university patenting across 300 universities and found that the U.S. dominates the patent landscape, but other countries, specifically China, are attempting to match the U.S. (Fisch, Hassel, Sandner, \& Block, 2015). Another study attempts to visualize the data on universityindustry collaboration across many disciplines (Feng, Zhang, Du, \& Wang, 2015). Kaushik and colleagues reviewed literature on challenges and barriers of the tech-transfer process and found 14 enablers of tech-transfer and 17 barriers across multiple institutions and developed a model to help assist the process (Kaushik, Kumar, Luthra, \& Haleem, 2014). Durack provides analysis of university professors publications and resulting relationships to patenting at universities. Durack concludes that researchers should not pursue research without paying attention to patenting law (Durack, 2006).

The authors found little discussion in the academic literature about the library's role within technology-transfer. The high point of the literature surrounding university libraries and technology transfer is in a Science \& Technology Libraries 1991 issue dedicated to the subject. In the issue, Woods (1991) highlights that "Indeed, it is this black hole of technology transfer information, that so hurts progress in this field. Those seeking federal technology need to obtain correct information, and they need

it rapidly." The author concludes that there is much potential for libraries to aid the process of technology transfer because of their knowledge of relevant databases and proficiency in searching those databases (p.44).

Engle (1991) also examines the role of public libraries in the technology transfer process and concludes, "It is a complex process growing from numerous individual acts of learning and creativity" which makes it difficult to truly assess or recognize the library's full role (p.98). Pensyl's (1991) article emphasizes the long and iterative process of working in the tech transfer pipeline and its potential value to complex searching. She concludes that librarians involved in the pipeline need no less than ten areas of specialized knowledge to be effective in this role.

Ebbinghouse (2008) and Sheppard (2007) predict increasing roles for librarians in the commercialization process, and focus analyses outside of the academic sphere, emphasizing opportunities for special libraries, consultants, and law libraries. MacDonald (2010) provides an excellent argument and visualizes the process in an Entrepreneurship Outreach Opportunities chart provided in the paper, Entrepreneurship Outreach: A New Role for the Academic Business Librarian (p.159). Since MacDonald's publication, the authors of this article have found surprisingly little in academic literature analyzing or supporting the role of libraries in the technology transfer process.

\section{Workflow business model - background and evolution}


A new unit was formed at the UA focusing on the commercialization of university technology called Tech Launch Arizona (TLA) in 2014. This unit encompasses the patenting and licensing of new technologies, regional ecosystem development, and economic development to support innovation and research within Arizona (Tumarkin, 2015).

In the early phases of the informal partnership, the librarians provided services for the unit in the form of business research instruction for student interns who worked within the technology transfer office. During this time, a proof-of-concept team was formed within TLA called the Business Intelligence Unit (BIU), which was tasked with advancing emerging technologies for next-stage development. These proof of concept (POC) projects are aimed at forwarding the commercialization and development of early-stage inventions as they relate to an identified need of the market. This group wanted to leverage the new relationship that was forming with the librarians. The librarians began providing business research for one POC project per month. It was piloted informally, with the understanding that this work was an open-ended process allowing both parties to further understand how the librarians and the POC group might partner. During the pilot phase, each individual research project required the librarians to gather market and industry research as well as scientific literature and patents. Some of the data gathered included market size, market opportunities, market segmentation, competitive information, scientific articles, and relevant patents. This work was completed during a 2-week period.

After several months of doing research for TLA, both parties concluded that this partnership was significant and held campus-wide value and impact. The commercialization unit and the librarians developed a proposal that outlined the work, and the library dean, librarians, and TLA met to discuss a more formalized program approach between the two units. After the units agreed to move forward, the library added two health-sciences librarians to the team and were able to formally add this work to their job assignments. In 2014, during the initial months after the partnership was officially formed, librarians met bi-weekly as members of the commercialization team to review progress of existing projects and discuss the needs for emerging projects. On average, each project by the librarians would take 10 to12 hours to complete. This included an initial conversation discussing questions posed by commercialization colleagues, conducting a literature search, reviewing the relevant articles and reports, and the writing up summaries of data and analyses based on an iterative back-and-forth dialog between librarians and commercialization-unit staff.

The newly formed TLA was rapidly iterating its own development and changing its alignment and workflows to reflect the needs of the campus units it served. In order to meet campus demand, the librarians needed to be agile to accommodate more projects while continuing to build understanding about the needs of TLA to achieve continued success. The commercialization unit hired a manager for the 
newly formed business-intelligence team, internal to TLA, who collaborated with the librarians to streamline the research process. TLA uses a start-up style approach, so the librarians working with the commercialization unit had to adapt quickly in addition to the work styles of each other. All of the librarians working on the team have invaluable experience working in industry. As the process changed quickly, the librarians were able to respond to the rapidly changing technology-transfer needs, the work flows of the group, and a certain level of ambiguity.

The work continued to evolve, and the librarians were involved with many new projects that came through the technology transfer process. This new workflow increased the output of projects completed; it was no longer feasible to spend 12 hours on each project without creating a bottleneck, so new processes were created. The group developed a "quick turn-around" workflow that shortened the process. Information gathered focused on specific elements of need that were easily available. Projects assigned have a 3-day turn around, which allows the business intelligence team time to review the content and provide analysis on each technology. These technologies are discussed at weekly meetings with TLA, where the librarians are invited to attend and contribute.

Campus projects originating from the commercialization unit are interdisciplinary; and $70 \%$ had a biomedical component (TLA, 2015). Due to the varying nature of the inventions, the skill sets needed for each project are often addressed by more than one librarian. Some of the skills needed include knowledge of subject and technical databases, market research, literature and patent-searching skills, and competitive intelligence. For example, librarians work together to provide information-decision support for a technology that improves the life of patients via a biomedical device. This type of project requires expertise in multiple areas such as searching the engineering and biomedical technical and patent literature, efficacy of the technology, epidemiology of disease, review of the market landscape to identify competing technologies, and review of potential opportunities for partnerships with an existing company, or identifying other opportunities in the market. Librarians often collaborate on projects, which allows for focused efforts and leverage of existing skill sets, which ultimately results in a stronger information picture for each emerging technology.

Developing new roles and responsibilities in the library alongside functional job duties requires persistent engagement, vision, and diplomacy. The librarians piloting this collaboration initially spent time educating the library about how technology transfer works, the value it brings to campus and the community, and how libraries could benefit from the intersection of this type of campus engagement. It is not easy for academic libraries to commit resources for new efforts that are untested, especially efforts that are not well defined. This type of embedded partnership is innovative as far as the authors are aware, and not typical for academic libraries. It requires an investment at the leadership level of both the library 
and the technology transfer units so that this type of partnership can be successful and transformative for both parties. In May of 2014, the librarians were officially named partners within the business intelligence unit of TLA.

\section{Challenges}

Developing clear communication channels and delineating work among several librarians was challenging. The librarians established an open dialog to discuss needs, feedback, and resources among each other as well as with the business intelligence manager. The quick turnaround requirements of the technology transfer unit requires that librarians are constantly checking in via a variety of communication and project management tools. The librarians reside in different departments and in different physical locations on campus, so communication is key to making this partnership work. When work for new projects is released, each librarian takes one or two projects to complete that week based on the number of project requests, the type of technology, and other work that the librarians are managing. Each librarian is responsible for self-identifying projects to complete and communicating that to the group. Every librarian works on at least one project per week. Projects are distributed based on expertise in a particular subject area, depending on librarian availability, the specific needs of the project, and turn-around time of each project. Librarians may work outside their disciplinary area in order to complete projects. The librarians and the commercialization group communicate regularly about ongoing research projects and hold a biweekly conference call to discuss workflows and projects.

Another ongoing challenge for the librarians is locating information using limited resources. Like most academic libraries, the UA does not possess every form of information resource and is limited in access to specialized market research and patent databases. Rather, the content and collections of a campus library reflect the needs of student and faculty researchers, and focus on providing access and value for the entire campus, not just for technology transfer needs. Despite this issue, the librarians were able to leverage access to existing information resources and competitive intelligence tools available to academic librarians and provide a good starting point for completing research for each technology. In circumstances where existing resources were insufficient or adequately meet the needs of the project, it was documented and information gaps were identified. These gaps were shared with the UAL and TLA to spur discussions about allocating resources to meet future needs. The discussions included developing a plan for finding additional funding resources and identifying specific resources that could potentially fit the information needs for future projects. Information professionals that search the literature and market landscape are positioned to demonstrate leadership and guidance in this area. 


\section{Results}

Since the collaboration began, a number of successful outcomes have taken place. Companies have been formed, patents have been filed, technologies have been evaluated, and next-stage developments have been identified. The librarians have been involved in multiple projects that led to successful business development manifested from those outcomes. The landscape of technologies come from various disciplines and colleges across campus. Specifically, UA's six IP generating colleges are engineering, science, medicine, management information systems (MIS), agriculture and life sciences, and optics (see Figure 1). The TLA Annual Report provides a good graphical overview of the 2015 reported inventions by field and college and provides a representation of types of projects of technologies (2015).

[Insert Figure 1 here]

Figure 1: FY2015 Inventions Metrics (Tech Launch Arizona, 2015)]

Since the inception of the BIU, 23 start-up companies have been built on UA-based licensed technology. This includes 11 from fiscal year 2014 and 12 from FY 2015, and a goal of 13 start-ups for FY 2016. Each start-up benefits from the early-stage assessment of the technology, patent and literature search, market analysis, partner or collaborator identification, competitive landscape development, and business case development. Examples of start-ups where the librarian's provided early stage assessment include companies such as Dataware Ventures, Glycosurf and Metropia (see Figure 2).

[Insert Figure 2 here]

Figure 2: A short summary of start-up companies resulting from early assessment of the BIU (Tech Launch Arizona, 2015)]

In addition to contributing to the early assessment of start-up companies, a number of successful patents have been filed. During the FY 2014, 167 patent applications were filed, with a successful 24 patents issued. In FY 2015, 200 patent applications were filed and 35 patents were successfully issued. This activity has led to 39 exclusive licensees in FY 2014 and 45 in FY 2015 (see Table 1).

[Insert Table 1 here] 
Table 1: Patents filed by the BIU

In the early-stage development arena, the BIU has assessed and supported proof-of-concept (POC) projects. Collaboration with the library has allowed the BIU to conduct early assessment and move these technologies closer to outside funding. Partnership with the librarians has directly supported 19 POC projects in FY 2014 for a total of \$416K. This partnership supported a more focused effort in FY 2015 , driving 17 POC projects with a total investment of $\$ 554 \mathrm{~K}$.

Overall, the BIU has provided early-stage analysis and developmental support for 223 technologies for TLA. Partnership with the librarians has not only enhanced the assessment of early technologies but has contributed to the development of executive summaries, technology summaries, commercial feasibility studies, opportunity assessments, and POC development plans, grant application support, and business case development.

\section{Impact}

The contributing work by the librarians has been recognized through two awards. The first was recognition by our partners at TLA with the I-Squared for Innovation and Impact Award for Campus Collaboration, most notably "in recognition of its partnership in providing research and business intelligence to support TLA's efforts in helping direct development of new UA technologies and startups" (Tumarkin, 2015). The team was also recognized by the Special Libraries Association's Academic Division with the Springshare Innovation in Academic Libraries Award. This award recognizes a new program or service that demonstrates and innovative approach to academic librarianship (Buckner, 2015). Since this is a new endeavour for the UA libraries that supports Never Settle, the UA's strategic plan, the team was recognized for its supportive and dynamic approach in Innovation by its partnership with TLA.

In conclusion, this partnership demonstrates the impact and value of librarians working within the campus commercialization process. This unique partnership took an innovative approach toward developing a sustainable relationship in working with TLA. As demonstrated by the number of companies and patents secured as well as identifying needs in the market landscape in the last 2 years, the benefits of utilizing librarians have had an impact on invention and commercialization at the UA as well as the regional economic development of the state. 


\section{References}

Aldridge, T. T., \& Audretsch, D. (2011). The Bayh-Dole Act and scientist entrepreneurship. Research Policy, 40(8), 1058-1067. doi:10.1016/j.respol.2011.04.006

Association of University Technology Transfer Managers. (2010). Bayh-Dole Act. Retrieved from https://www.autm.net/advocacy-topics/government-issues/bayh-dole-act/

Association of University of Technology Transfer Managers. (2014). Licensing Activity Survey: FY2014. Retrieved from https://www.autm.net/resources-surveys/research-reports-databases/licensingsurveys/fy-2014-licensing-survey/

Buckner, T. (2015, June 23). Congratulations to our award winners! Retrieved from http://academic.sla.org/annual-conference/congratulations-to-our-award-winners.html

Dewland J., \& Elliott, C.M. (2015). Embedding libraries in the university commercialization process. In B. Eden (Ed.) Partnerships and new roles in the 21st-century academic library: Collaborating, embedding, and cross-training for the future (pp. 41-50). Washington, D.C. Rowman \& Littlefield.

Durack, K. (2006). Technology transfer and patents: Implications for the production of scientific knowledge. Technical Communication Quarterly, 15(3), 315-328. doi:10.1207/s15427625tcq1503_3

Ebbinghouse, C. (2008). Technology transfer heats up. Searcher, 16(8), 8-11; 59-60. Medford:Information Today, Inc.

Engel, C. (2016). The public library:A key to technology transfer. Science \& Technology Libraries, 11(2), 89-99. doi: 10.1300/J122v11n02_08

Fairburn, E., \& Hallman, F. (2013). Entrepreneurship by university scientists and the Bayh-Dole Act. Hauppauge, NY: Nova Science Publishers, Inc. Retrieved from http://www.ebrary.com

Feng, F., Zhang, L., Du, Y., \& Wang, W. (2015). Visualization and quantitative study in bibliographic databases: A case in the field of university-industry cooperation. Journal of Informetrics, 9(1), 118134. doi:10.1016/j.joi.2014.11.009 
Fisch, C. O., Hassel, T. M., Sandner, P. G., \& Block, J. H. (2015). University patenting: A comparison of 300 leading universities worldwide. Journal of Technology Transfer, 40(2), 318-345.

http://doi.org/10.1007/s10961-014-9355-X

Geiger, R. L. (2004). Knowledge and money:Research universities and the paradox of the marketplace. Stanford, Calif. Stanford University Press.

Geiger, R. L., \& Sa, C. M. (2008). Tapping the riches of science:Universities and the promise of economic growth. Cambridge, Mass. Harvard University Press.

Grimaldi, R., Kenney, M., Siegel, D. S., \& Wright, M. (2011). 30 years after Bayh-Dole: Reassessing academic entrepreneurship. Research Policy, 40(8), 1045-1057.

http://doi.org/10.1016/j.respol.2011.04.005

Kaushik, A., Kumar, S., Luthra, S., \& Haleem, A. (2014). Technology transfer:Enablers and barriers - a review. International Journal of Technology, Policy and Management, 14(2), 133-159. doi:10.1504/IJTPM.2014.060152

Lolse, V., \& Stevens, A.J. (2010). Bayh-Dole Act. Retrieved from http://www.bu.edu/otd/files/2011/02/The_Bayh-Dole_Act_Turns_30.pdf

MacDonald, K. (2010). Entrepreneurship outreach: A new role for the academic business librarian. Journal of Business \& Finance Librarianship, 15(3-4), 158-160.

doi:10.1080/08963568.2010.490767

Mowery, D. C., Nelson, R. R., Sampat, B. N., \& Ziedonis, A. A. (2001). The growth of patenting and licensing by U.S. universities: An assessment of the effects of the Bayh-Dole act of 1980. Research Policy, 30(1), 99-119. doi:10.1016/S0048-7333(99)00100-6

Nelson, A., \& Byers, T. (2015). Challenges in University Technology Transfer and the Promising Role of Entrepreneurship Education. In A. N. Link, D. S. Siegel, \& M. Wright (Eds.), The Chicago Hand book of University Technology Transfer and Academic Entrepreneurship (p. 320). Chicago, IL: University of Chicago Press.

Pensyl, M. (1991). Technology transfer process: Emerging roles for academic librarians in the technology transfer process. Science \& Technology Libraries, 11(2), 29-38. doi:10.1300/J122v11n02_03 
Sheppard, J. (2007). How much is that gizmo in the window? Online technology transfer and commercialization resources. Online, 31(6), 41-46. Retrieved from http://ezproxy.library.arizona.edu/login?url=http://search.ebscohost.com/login.aspx?direct=true \&db $=$ rzh $\& A N=105904936 \&$ site $=$ ehost-live

Siegel, D. S., \& Wright, M. (2015). University technology transfer offices, licensing, and start-ups. In A.N. Link, D.S. Siegel, \& M. Wright (Eds.), The Chicago Hand book of University Technology Transfer and Academic Entrepreneurship (p. 320). Chicago, IL: University of Chicago Press.

Woods, D. L. (1991). American libraries and domestic technology transfer. Science \& Technology Libraries, 11(2), 39-47. doi:10.1300/J122v11n02_04

Tech Launch Arizona. (2015). Creating and connecting an ecosystem of university invention and commercialization. 2015 Annual Report and Roadmap Update. Retrieved from http://techlaunch.arizona.edu/sites/default/files/documents/2015/tech-launch-arizona-annual-report2015-10-15.pdf.

Tumarkin, P. (2015, May 01). University of Arizona I-squared awards event honors impact and innovation in technology commercialization. Tech Launch Arizona. Retrieved from $\mathrm{http} / / /$ techlaunch.arizona.edu/news/university-arizona-i-squared-awards-event-honors-impact-andinnovation-technology 
Table 1. Patents filed by the BIU

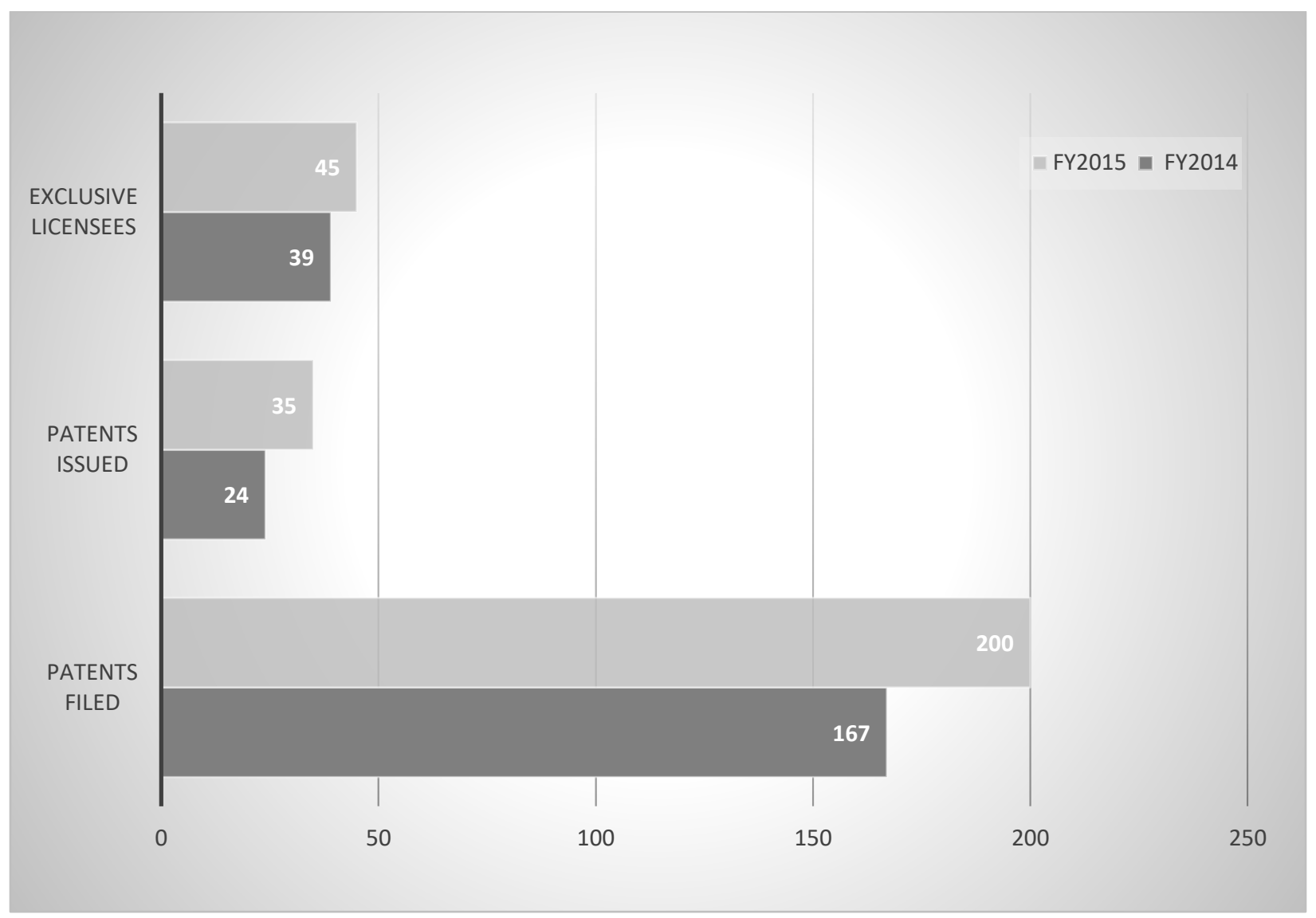

